\title{
Dissent and the First World War, Conference, Wellington, 31 August- 2 September 2017 Conference Report
}

\author{
PETER CLAYWORTH
}

Since 2014, there has been a continual stream of official commemorations of the Great War's centennial. The "Dissent and the First World War" conference, held in Wellington over 31 August to 2 September, demonstrated the importance of commemorating the counter-narratives of wartime dissent, offering a wide-ranging coverage of that dissent's many faces. The conference was organised by the Stout Centre and the Labour History Project, with assistance from ARANZ (the Archives and Records Association of New Zealand) and the Ministry for Culture and Heritage.

The three keynote speakers provided an imperial context in which for the activities of New Zealand's dissenters can be comparatively understood. Cyril Pearce, of the University of Leeds, spoke of towns such as Huddersfield, in Northern England, where conscientious objection (CO) and war resistance had relatively high profiles. Pearce discussed dissent in these towns in the context of the local religious, political and feminist communities. Joan Beaumont, of the Australian National University, gave a fascinating comparative account of the conscription debates in Australia and New Zealand. She outlined the reasons behind differences between the Dominions, with Australia twice rejecting conscription in public referenda, whereas the New Zealand Government introduced conscription as a fait accompli. Her lecture was particularly valuable for a New Zealand audience, given our general lack of knowledge of the Australian conscription story. David Grant, public historian extraordinaire, spoke on "The Seditionists and their Heritage." He examined the way in which labour leaders imprisoned for sedition in the Great War, such as Peter Fraser, Bob Semple and Paddy Webb, became the politicians who crushed dissent in the Second World War. In the process, Grant discussed the contested attitudes within the New Zealand Labour Party to war and conscription. The three keynote lectures taken together helped position New Zealand as a part of the British Empire in a world-wide war. They also set the New Zealand labour and peace movements in the context of these global campaigns.

My major complaint about the Dissent conference was its embarrassment of riches, forcing tough decisions over which talks to attend in the opposing streams. The conference many excellent papers on aspects of the labour movement opposition to conscription. Many papers looked at transnational connections, as with Samuel Denny's paper on working class radicalism in New Zealand and the USA. Emma Kelly's paper, on the political poetry of Harry Holland, a significant figure in both the Australian and New Zealand labour movements, discussed one dissenter's literary response to war and capitalism. A dissenting note within the Dissent conference was struck by West Coast local historian Norman Crawshaw: he presented a paper highly critical of the role of mining unionists during the war, which in turn raised strong disagreement from several members of his audience.

Another clear theme at the conference was state repression as a response to dissent. Jared Davidson discussed surveillance and censorship; Rowan Carroll examined police actions against draft dodgers; and Mark Derby and Margaret Lovell-Smith were among those looking at the imprisonment of war resisters and seditionists. The examination of state power was further nuanced by John Crawford's paper. Crawford argued that Defence Minister James Allen walked a tightrope between the Government's own relatively liberal inclinations and strong pressure from a vociferous anti-German and anti-CO section of the public, well represented by backbench MPs. The idea that war increased the state's repression of those who challenged societal norms was explored in Sally Maclean's paper 
on the mysterious case of Dr von Dannevill, a "foreign" woman who fell afoul of anti-German hysteria.

The complexities of Māori involvement in the Great War were addressed in a discussion between Paul Meredith, of Ngāti Maniapoto, and Monty Soutar, of Ngāti Porou. They examined King Te Rata's statement to his followers, telling them to make their own decisions on whether to fight. Meredith and Soutar considered that most "Kingites" regarded this as an instruction not to volunteer, but pointed out that a small minority of Waikato and Ngāti Maniapoto men did enlist. Meredith and Soutar described the state's targeting of the King's family, as the Government attempted to conscript Waikato-Tainui men.

Puawai Cairns addressed a particular aspect of Māori dissent: the role of mothers who tried (sometimes successfully) to get their sons back out of the army before they could go to war. Cairns argued this was a precursor to Te Puea's actions on a larger scale later in the war. Kingitanga opposition to war, including the conflict between Te Puea and Maui Pomare and the role of waiata (songs), was also discussed in papers by Therese Crocker and Rachel Gillett. There was, unfortunately, no paper that dealt in depth with the wartime dissent and arrest of the prophet Rua Kenana, nor examination of the Tuhoe position during the war.

In addition to the actions of Te Puea and Māori mothers, a number of papers discussed forms of Pākehā women's dissent. Nellie-Goodwin Welch's paper examined the very personalised reactions of grieving mothers in Australia and New Zealand. She argued that the open expression of grief, rather than stoic acceptance, was in itself a form of dissent. Megan Hutching's paper "Why War is Women's Business" looked at the public political actions of anti-war activists such as Adela Pankhurst and the members of the Women's International League for Peace and Freedom.

Some of papers on $\mathrm{CO}$ and state coercion touched on the role of Irish nationalists, but Sean Brosnahan's "Loyal Sons of Erin" examined this subject in detail. Brosnahan explored the small but important Irish resistance movement in New Zealand and its links to the wider Irish nationalist cause. As a counterpoint, Brad Patterson's paper on Howard Elliot and the Protestant Political Association discussed how the war stimulated the growth of sectarian bigotry.

A number of papers looked at the reactions of local institutions and communities to the war, including elements of dissent. Warwick Johnson's paper examined changing attitudes to the war from within the Petone Borough Council, while Julia Stuart looked at a range of dissenting attitudes in the Eastbourne community. James Braund discussed the reaction to war of another small New Zealand community: scientists. He argued that, by keeping a low profile, New Zealand scientists were able to maintain their professional links with their German and Austrian colleagues, despite the war and widespread anti-German sentiment. Steven Loveridge looked at a large but now forgotten community group, the Second Division League of married men subject to the draft. It was fascinating to hear of a "riot" in Christchurch involving protest by this avowedly patriotic group.

The Dissent conference featured a number of papers dealing with the representation and memorialisation of dissent. Alan Jackson described the struggle in Dunedin to establish a memorial to Archibald Baxter and the 14 resisters forcibly sent to the front in 1917. Bob Kerr discussed his own role in painting artworks based on the story of these resisters, while Russell Campbell gave a critical analysis of the TV film on this subject, Field Punishment No. 1. The role of music in representing dissent was also much discussed: in addition to the already-mentioned discussion of waiata, there was a musical "paper" presented by Marie Russell, Garry Smith, Sarah Donovan and 
Kevin Iken, consisting of songs about "Dodgers and Deserters" from a range of New Zealand's conflicts.

Sarah Dunbar spoke on Quaker resistance to war as traced through the Religious Society of Friends papers in Auckland University. Throughout the conference there was serious discussion of the way the activities of dissenters can be traced through official and unofficial records. The role of religious objectors was touched on in a number of other papers, but the wider role of religion and the motives of religious objectors were subjects that could have done with more examination. I would also like to have seen discussion of such subjects as the debates within the labour movement about war and conscription. For example, did many of those who had actively opposed compulsory military training before the war join up and fight once the war started? However, while there are always subjects that could be added to the mix, my overall impression of the Dissent and the First World War conference was of a wide ranging, stimulating and extremely informative event. 